\title{
Effects of acute and chronic physical exercise and stress on different types of memory in rats
}

\author{
PÂMELA BILlig MELLO ${ }^{1,2}$, FERNANDO BENETTI ${ }^{1,2}$, MARTÍN CAMMAROTA $^{2}$ and IVÁN IZQUIERDO $^{2}$ \\ ${ }^{1}$ Programa de Pós-Graduação em Ciências Biológicas: Fisiologia, Instituto de Ciências Básicas da Saúde, \\ Universidade Federal do Rio Grande do Sul (UFRGS), Rua Sarmento Leite 500, $2^{\circ}$ andar, \\ 90050-170 Porto Alegre, RS, Brasil \\ ${ }^{2}$ Centro de Memória, Instituto de Pesquisas Biomédicas, Pontifícia Universidade Católica do Rio Grande do Sul (PUCRS), \\ Av. Ipiranga 6690, $2^{\circ}$ andar, 90610-000 Porto Alegre, RS, Brasil \\ Manuscript received on August 17, 2007; accepted for publication on November 15, 2007; \\ contributed by IVÁN IZQUIERDO*
}

\begin{abstract}
Here we study the effect of acute and chronic physical exercise in a treadmill and of daily stress (because forced exercise involves a degree of stress) during 2 or 8 weeks on different types of memory in male Wistar rats. The memory tests employed were: habituation in an open field, object recognition and spatial learning in the Morris water maze. Daily foot-shock stress enhanced habituation learning after 2 but not after 8 weeks; it hindered both short- (STM) and longterm memory (LTM) of the recognition task at 2 weeks but only STM after 8 weeks and had no effect on spatial learning after either 2 or 8 weeks. Acute but not chronic exercise also enhanced habituation in the open field and hindered STM and LTM in the recognition task. Chronic exercise enhanced one important measure of spatial learning (latency to escape) but not others. Our findings indicate that some care must be taken when interpreting effects of forced exercise on brain parameters since at least part of them may be due to the stress inherent to the training procedure.
\end{abstract}

Key words: physical activity, stress, learning and memory, forced running.

\section{INTRODUCTION}

The functional benefits of physical exercise on brain function have been studied in humans (Winter et al. 2007, Arkin 2007, Abbot et al. 2004) and also in laboratory animals, especially rodents. Regular physical activity has been related to improvement of cognitive function in rats (Kramer et al. 1999, Sutoo and Akiyama 2003, Cotman and Berchthold 2002, Berchthold et al. 2005). Physical exercise modulates hippocampal neurogenesis (During and Cao 2006, Fabel et al. 2003, van Praag et al. 1999), reduces oxidative stress (Ogonovszky et al. 2005, Radak et al. 2006), increases brain-derived neurotrophic factor levels (Vaynman et al. 2006, Huang et al. 2006, Berchtold et al. 2005, Neeper et al. 1995) and brain vascu-

\footnotetext{
*Member Academia Brasileira de Ciências

Correspondence to: Iván Izquierdo

E-mail: izquier@terra.com.br
}

larization (Isaacs et al. 1992), and causes a variety of morphological changes (Arida et al. 2004).

Several authors have reported favorable effects of physical exercise on memory (Barnes et al. 1991, Uysal et al. 2005, VanPraag et al. 2005, Blustein et al. 2006, Ang et al. 2006, Ogonovsky et al. 2005, Radak et al. 2006, Alaei et al. 2006). Most studies in rodents were carried out using voluntary exercise such as free wheel running (eg. Van Praag et al. 2005) but few investigated the effects of forced exercise (see Ang et al. 2006, Radak et al. 2006). The latter, which is much used by humans (eg., Winter et al. 2007), probably involves a degree of stress (Cotman and Bertchtold 2002, Ang et al. 2006, Blustein et al. 2006, Winter et al. 2007), which is difficult to control. Only few authors have studied, animals submitted for similar periods to other forms of stress besides that provided by physical exercise (see Berchthold 
et al. 2005, Ang et al. 2006, Blustein et al. 2006). Stress, especially if subacute or chronic, can produce profound alterations on memory processing (McEwen and Magarinos 2001, McGaugh 2004, 2005, 2006, Das et al. 2005, Manikandan et al. 2006, Radley et al. 2005). Consequently, it is important to distinguish the effects caused by the exercise itself from those produced by the stress inherent to physical exercise.

Here we investigate the effects of acute and chronic physical training in a treadmill and of daily exposure to 5 min mild footshock stimulation on three different learning tasks: habituation of exploration in an open field, object recognition and the Morris water maze.

\section{MATERIALS AND METHODS}

\section{ANIMALS}

One hundred and twelve male Wistar rats purchased at Centro de Reprodução e Experimentação Animal (CREAL) from Universidade Federal do Rio Grande do Sul (UFRGS) were used. The animals were housed into plastic cages under a light/dark cycle (lights on at 7:00 AM), with water and Purina lab chow freely available and at a constant temperature of $23^{\circ} \mathrm{C}$. The animals started the physical training with 45 or 80 days old (for animals trained for 8 or 2 weeks, respectively). In consequence, they were around 100 days old when they were submitted to behavioral testing.

All efforts were made to minimize animal suffering and to reduce the number of animals used. In all experiments the "principles of laboratory animal care" (NIH publication $\mathrm{N}^{\circ} 85-23$, revised 1996) were strictly followed.

\section{Behavioral Procedures}

Animals were separated in four experimental groups, as follows: acute exercise (for 2 weeks), acute stress (for 2 weeks), chronic exercise (for 8 weeks) and chronic stress (for 8 weeks). Each group was further divided in two sub-groups: experimental and control. After the physical exercise period, the animals were tested in three different memory tests: open field, object recognition and Morris water maze.

\section{PhysicAl EXERCISE PROTOCOL}

Animals were submitted to protocols of acute ( 2 weeks) or chronic physical exercise ( 8 weeks) in a treadmill (see below). Prior to exposure to the exercise or stress, all animals were placed in the training apparatus for $10 \mathrm{~min}$ during the first week in order to minimize noveltyinduced stress.

In the first day of the second week an incremental test was carried out on an adapted motorized rodent treadmill (INBRAMED TK 01, Porto Alegre, Brazil) to determine the physical exercise intensity that would be used in the training period. The indirect measurement of oxygen uptake $\left(\mathrm{VO}_{2}\right)$ peak was measured as recommended by Brooks and White (1978). Each rat ran for $25 \mathrm{~min}$ on the treadmill at a low initial speed followed by increases of speed of $5 \mathrm{~m} / \mathrm{min}$ every 3 minutes until they reached their point of exhaustion (i.e, failure of the rats to continue running). The time to fatigue (in minutes) and workload (expressed by velocity in $\mathrm{m} / \mathrm{min}$ ) were taken as indexes of capacity for exercise, and as a measure of $\mathrm{VO}_{2}$ peak.

This measure was used to control the exercise intensity during the physical training program. The intensity of the physical training protocol (50 $\mathrm{min} /$ day 5 day/week) was adapted for each animal so it never surpassed $60-75 \%$ of the respective maximum oxygen uptake. Each training session started with a 10 min-long warm-up (gradual acceleration) followed by $30 \mathrm{~min}$ at $60-75 \%$ level of the maximum oxygen consumption. The last 10 min of each session were for gradual deceleration.

The running sessions were conducted between 10:00 $\mathrm{AM}$ and 14:00 PM on an adapted motorized rodent treadmill with individual $10 \mathrm{~cm}$ wide, $50 \mathrm{~cm}$ long lanes separated by acrylic walls. Neither electric shock nor physical prodding was used in this study. Those animals that refused to run were encouraged by gently tapping on their backs. Animals that were not able to perform the exercise were excluded of the sample. The sedentary group was transported to the experimental room and handled exactly as the experimental animals but were not submitted to the forced running protocol (adapted from Scopel et al. 2006). To do that the animals were daily put in the running lanes with the treadmill off for ten minutes, and then returned to their home cages.

\section{StRess Protocol}

Animals were submitted to acute ( 2 weeks) or chronic stress ( 8 weeks). To do that we used a $50 \times 25 \times$ $25 \mathrm{~cm}$ acrylic box whose floor was made of a grid of 
parallel bronze bars $1 \mathrm{~cm}$ apart. The animal received a 0,4 mA, 2-seconds footshock every 30 seconds during 5 min (adapted from Cao et al. 2007), five times a week during 2 or 8 weeks. There was no apparent tissue damage observed in the footpads of shocked rats. The control group was transported to the experimental room and handled exactly as the experimental animals, but did not receive footshocks.

\section{OPEN-FIELD TEST}

To analyze exploratory and locomotor activities, as well as habituation memory, animals were placed on the left rear quadrant of a $50 \times 50 \times 39 \mathrm{~cm}$ open field with white walls and floor divided into 12 equal rectangles by black lines on the floor. The number of line crossings and the number of rearings were measured over 5 minutes. These are classical measures of locomotor and exploratory activities. Twenty-four hours later, animals were left to explore the apparatus again for another 5 minutes and the same measures were recorded to evaluate habituation to the task (Barros et al. 2006).

\section{Object Recognition Test}

The object recognition test (Ennaucer and Delacour 1988) was carried out one in the same arena used for the open field test, as described by Dere et al. (2005). All animals were habituated to the experimental arena in the absence of any specific behavioral stimulus for $20 \mathrm{~min} /$ day during 4 days. The objects, made of metal or glass, were fixed to the arena's floor with adhesive ribbon. In the first day (training session) the animals were placed in the arena containing two different objects ( $\mathrm{M}$ and $\mathrm{N}$ ) and left to explore them freely for 5 minutes. The test was repeated 180 minutes later to test short-term memory (STM) or 24 hours later to evaluate long-term memory (LTM) after the physical training program. In the tests, one of the objects was changed for a new object (P, for STM or R, for LTM) and the rat was introduced in the arena for more 5 minutes. The positions of the objects (familiar or novel) were randomly permuted for each experimental animal and the arena was cleaned between trials. Exploration was defined as sniffing or touching the object with the nose and/or forepaws. Sitting on or turning around the object was not considered exploratory behavior. The time spent to explore each ob- ject was recorded by an observer blind to the treatment and expressed as a percentage of the total exploration time computed in seconds (Rossato et al. 2007).

\section{MORRIS WATER MAZE (MWM)}

The water maze was a black circular pool $(200 \mathrm{~cm}$ in diameter) conceptually divided in four equal imaginary quadrants for the purpose of data analysis. The water temperature was maintained between $21-23^{\circ} \mathrm{C}$. Two centimeters beneath the surface of the water and hidden from the rats view there was a black circular platform of $12 \mathrm{~cm}$ in diameter. It had a rough surface, which allowed the rat climbing onto it easily once detected. The swimming path of the rats was recorded using a video camera mounted above the center of the pool and analyzed using a video tracking and analysis system. The water maze was located in a well-lit white room with several posters and other distal visual stimuli hanging on the walls to provide spatial cues. A curtain separated the water maze room from the room where the computer setup was installed and the animals were temporarily housed during the behavioral sessions. Morris water maze training period began 24 hours after the object recognition test and was carried out during five consecutive days (Rossato et al. 2006b). A 5-day training-test procedure was employed. This is more sensitive to the analysis of different parameters of spatial learning (Rossato et al. 2006b, 2007) than the 1-day protocol (Frick et al. 2000) preferred by some (eg., Ang et al. 2006). On each training day/session, the rats received eight consecutive training trials while the hidden platform was kept in constant position. A different starting location was used for each trial, which consisted of swimming followed by a 30 seconds platform sit. Rats who did not find the platform within 60 seconds were guided to the platform by the experimenter. Memory retention was evaluated during a 30 seconds probe trial carried out 24 hours after the last training session in the absence of the escape platform (Rossato et al. 2006a).

\section{STATISTICAL ANALYSIS}

Duncan multiple range tests were used to make comparisons between various groups, and Student's $t$-test was used to compare each group against its control. 
A

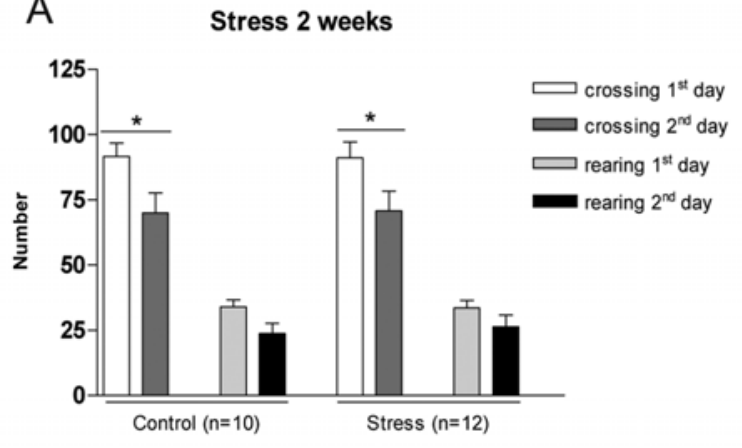

C

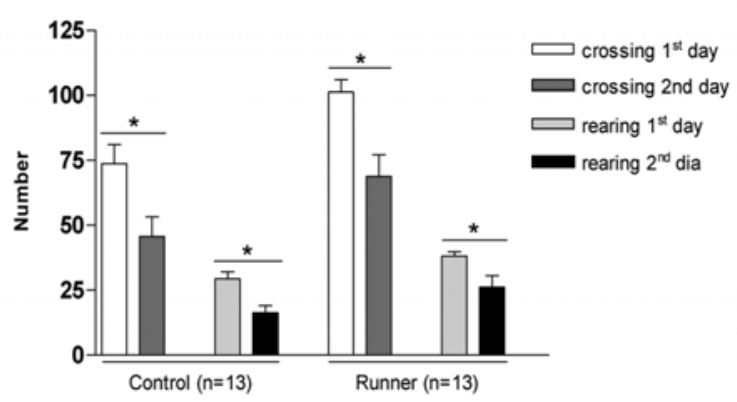

B

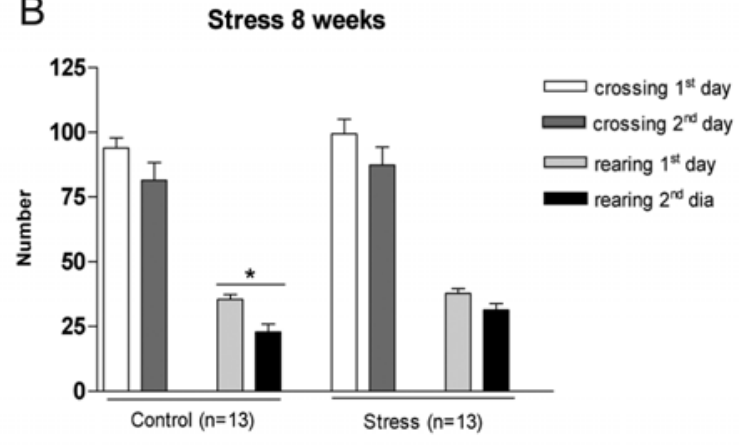

D

Exercise 8 weeks

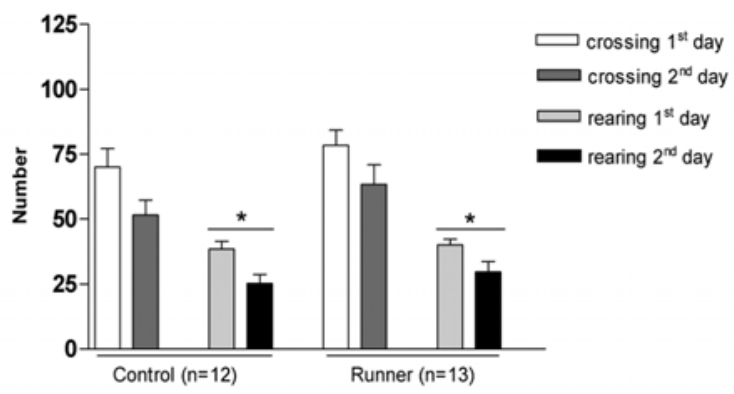

Fig. 1 - Effects of daily footshock stress for 2 (A) or 8 weeks (B), and of forced exercise during 2 (C) or 8 weeks (D) on the habituation of exploration on an open field (OF). Animals were placed for $5 \mathrm{~min}$ in the OF (training session) and $24 \mathrm{~h}$ later were submitted to a similar exposure (test session). Values are expressed as means \pm SEM of crossings and rearings. $\mathrm{N}$ indicated in each figure. Each graph compare the experimental and control groups; ${ }^{*} \mathrm{p}<0.05$ (training $\times$ test) in a Student's $t$-test.

\section{RESULTS}

\section{OPEN-FIELD TEST}

Both daily stress (Fig. 1A) and forced running protocols (Fig. 1C) enhanced habituation learning after 2 weeks (acute), but not after 8 weeks of training (chronic) (Figs. 1B and 1D).

\section{ObJect Recognition Test}

Acute stress impaired both short- (STM) and long-term object recognition memory (LTM) while chronic stress hampered only LTM (Fig. 2A and Fig. 2B). Similarly, acute physical exercise also hindered short- and longterm object recognition memory (Fig. 2C). However, chronic forced exercise did not affect short-or long-term memory retention (Fig. 2D).

\section{MORRIS WATER MAZE}

Neither stress nor physical exercise, chronic or acute, had any effect on spatial memory acquisition or retention (Fig. 3A and Fig. 3B). However, chronic physical exercise induced a clear decrease in the latency to swim over the previous location of the escape platform during a probe test carried $24 \mathrm{~h}$ after the last training session (Fig. 3C). No difference in swimming speed was observed among experimental groups.

\section{ANALYSIS OF MAXIMUM OXYGEN UPTAKE}

On the first day of the $5^{\text {th }}$ week of training, animals submitted to the physical exercise protocol were submitted to a second measurement of maximum oxygen uptake to analyze whether the training protocol was effective. All animals increased their maximum oxygen uptake, 

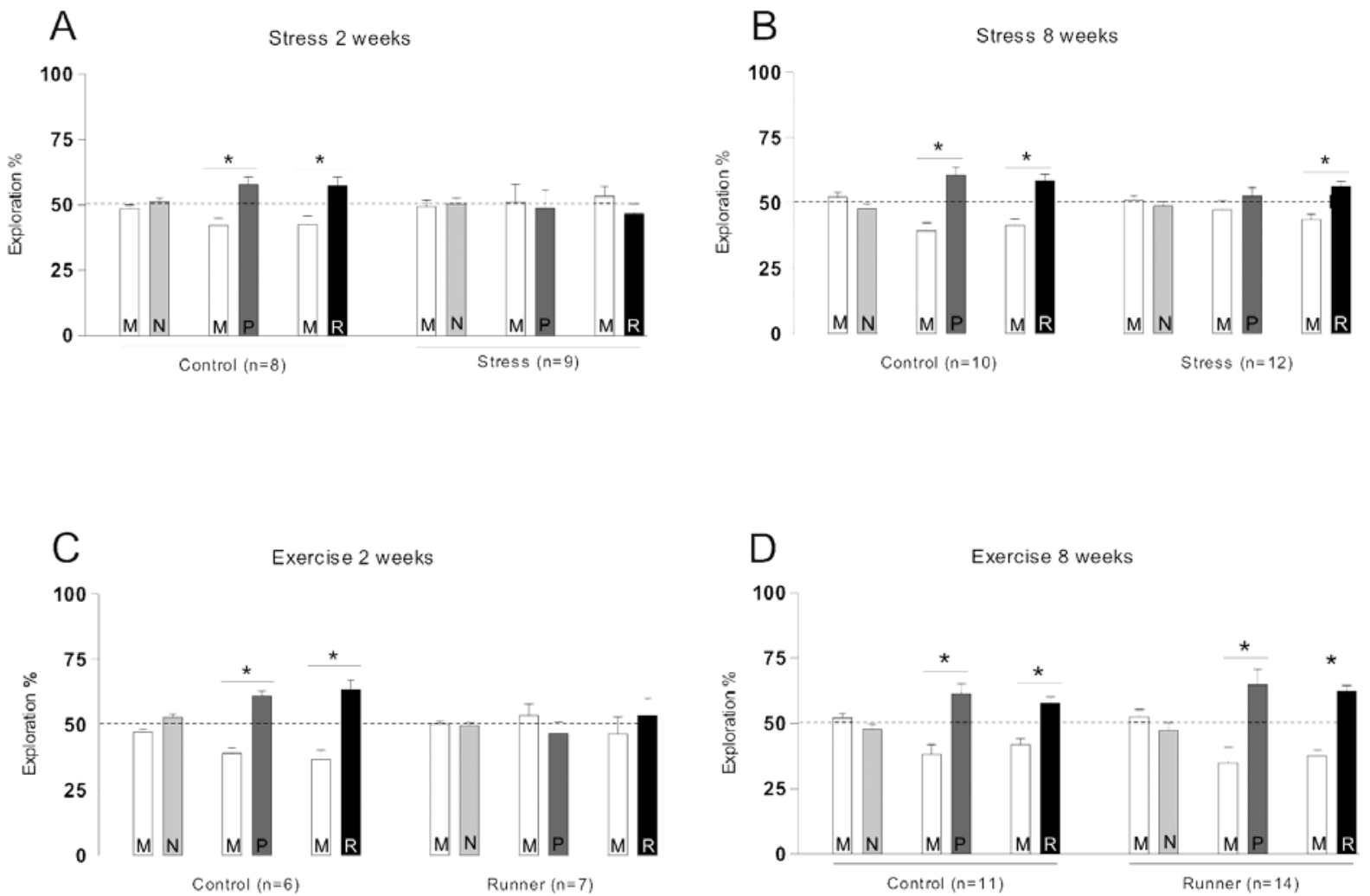

Fig. 2 - Effects of daily footshock stress for 2 (A) or 8 weeks (B) and of forced exercise during 2 (C) or 8 weeks (D) on object recognition memory. Rats were exposed to two different objects ( $\mathrm{M}$ and $\mathrm{N}$ ) for $5 \mathrm{~min}$ in the training session. Three hours later a short-term memory (STM) test was carried out: animals were exposed to a familiar object (M) and a novel object (P) again for 5 min. Long-term memory (LTM) was measured $24 \mathrm{~h}$ after training: the animals were exposed again to the familiar object (M) and to another novel object (R) for 5 min. Data are presented as means \pm SEM of the percentage of time spent exploring a particular object divided by the total time of object exploration. ${ }^{*} \mathrm{p}<0.05$ in Student's $t$-test.

indicating that forced running protocol indeed enhanced physical aerobic capacity (Fig. 4). Maximum oxygen uptake was not evaluated at the end of the training period to avoid confounding strin the end of running period because this test can cause some stress to the animals, and immediately after the exercise protocol was finished the animals were submitted to the memory tests.

\section{DISCUSSION}

The effects of daily forced exercise and daily footshock stress were quite similar, but not identical in the three tasks here examined. Our results fall within the wide variability of reports in the literature on the nature of these effects (van Praag et al. 2005, Ogonovsky et al. 2005, Uysal et al. 2005, Radak et al. 2006, Blustein et al. 2006, Alaei et al. 2006, Ang et al. 2006). Further, our findings correlate with others in humans showing that high impact running improves some forms of learning, but also causes blood catecholamine and other changes indicative of stress (Winter et al. 2007).

Both procedures were followed by an enhancement of habituation learning but not of within-session performance of crossings or rearings in the open field (Fig. 1).

The two treatments impaired object recognition learning after 2 weeks, suggesting that the effect of acute exercise could be at least in part attributed to the inherent stress. At 8 weeks, only the deleterious effect of chronic stress on this task persisted, while the animals submitted to chronic forced exercise showed a behavioral performance not different from untreated controls (Fig. 2). The effect of chronic stress or forced exercise on recognition learning had not been previously studied, to our knowledge. 

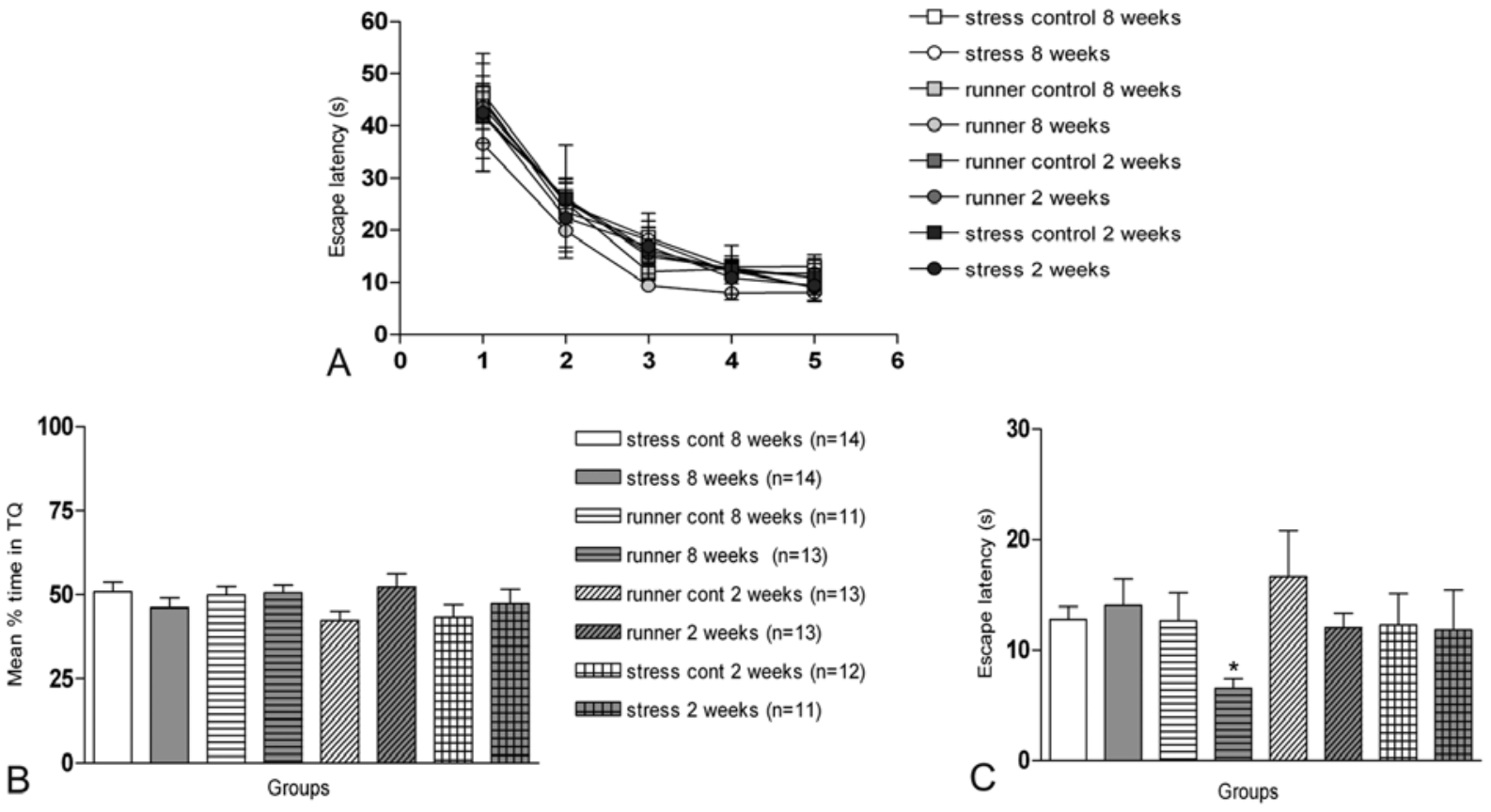

Fig. 3 - Animals were trained during 5 days in a spatial version of the Morris Water Maze (MWM). (A): Mean \pm SEM escape latency (time spent to find the escape platform) on each training session (data shown as blocks of 8 trials). (B): Mean \pm SEM time spent to find the target quadrant (TQ) during a $60 \mathrm{~s}$ probe test carried out $24 \mathrm{~h}$ after the $5^{\text {th }}$ training session; no significant differences among groups were detected. (C): Mean \pm SEM latency, measured in the probe test, to detect the position where the escape platform had been during the training. Animals submitted to the forced exercise during 8 weeks showed a significantly lower latency than all the others $\left({ }^{*} p<0,05\right.$ in Duncan's test).

Indirect $\mathrm{VO}_{2}$ peak

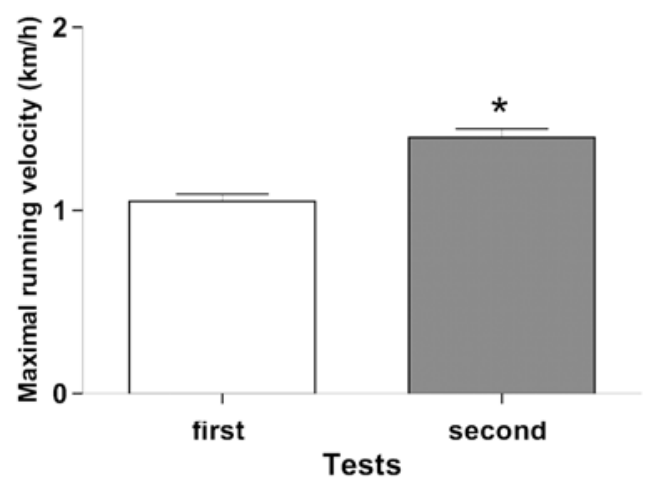

Fig. 4-Animals submitted to forced running during 8 weeks were submitted to two indirect measurements of maximum oxygen consumption $\left(\mathrm{VO}_{2}\right.$ peak) using the procedure of Brooks and White (1978). The first measurement was one day before the beginning of training, and the second was after 4 weeks of training. Note that the training procedure significantly enhanced $\mathrm{VO}_{2}(* \mathrm{p}<0,05$ in Student's $t$-test), showing that it effectively served the purpose of an exercise.
Finally, a slight but significant enhancing effect of chronic exercise was observed in the Morris maze (Fig. $3 \mathrm{C}$ ), which agrees with a report of Ang et al. (2006); Alaei et al. (2008) and with those of Radak et al. (2006) and Blustein et al. (2006). No such influence or any others were detected in the acute or chronic stress groups or in the acute exercise group.

In summary, our results suggest that while physical exercise can play a key role to influence the learned behavior in rats, the amount of stress inherent to each experimental procedure also has a prominent effect. It is difficult to establish exactly the degree of stress associated with the physical exercise protocol utilized in our experiments. However, it is clear that since it forces the animal to run at the experimenter demand, running in a treadmill is far more stressing than doing so, at will, in a running wheel (Blustein et al. 2006).

What is the biochemical basis of the behavioral modifications that we observed? Mechanisms to support our results may involve hippocampal neurogenesis 
(During and Cao 2006, Fabel et al. 2003, van Praag et al. 1999), reduced oxidative stress (Ogonovszky et al. 2005, Radak et al. 2006), and increased brain-derived neurotrophic factor levels (Vaynman et al. 2006, Huang et al. 2006, Berchtold et al. 2005, Neeper et al. 1995).

In any case, the question that remains open is how the influence of exercise on cognitive function can be ascribed to the exercise and stress separately (McEwen and Magarinos 2001, Cotman and Berchtold 2002), since the forced exercise per se also includes a degree of stress as suggested by stress oxidative investigations (Radak et al. 2006, Ogonovsky et al. 2005). Proper experiments are in course to answer this issue.

\section{ACKNOWLEDGMENTS}

This work was supported by research grants from the Conselho Nacional de Desenvolvimento Científico e Tecnológico (CNPq) to II and MC. The authors thank Dra. Adriane Belló Klein for her technical advice.

\section{RESUMO}

Neste trabalho estudamos os efeitos do exercício forçado diário em esteira rolante e da exposição diária ao estresse (porque o exercício forçado envolve um certo grau de estresse) durante 2 ou 8 semanas em diferentes tipos de memória em ratos Wistar machos. Os testes de memória utilizados foram: habituação da exploração em um campo aberto, reconhecimento de objetos, e memória espacial no labirinto aquático de Morris. O estresse diário facilitou a memória de habituação, os animais aprenderam após 2 mas não após 8 semanas; houve prejuízo na memória curta (STM) e de longa duração (LTM) no teste de reconhecimento em 2 semanas, mas somente de STM após 8 semanas; não houve nenhum efeito na memória espacial após 2 ou 8 semanas. O protocolo do exercício facilitou também a memória de habituação no campo aberto após 2 mas não após 8 semanas; prejudicou STM e LTM na tarefa do reconhecimento após 2 mas não após 8 semanas; e facilitou uma medida importante da aprendizagem espacial após 8 semanas (latência de escape), mas não outras medidas. Nossos resultados indicam que algum cuidado deve ser tomado ao se interpretar efeitos de exercício forçado sobre as funções cognitivas, já que uma parte deles, embora não todos, podem ser atribuídos ao estresse inerente ao exercício.

Palavras-chave: atividade física, estresse, aprendizagem e memória, corrida forçada.

\section{REFERENCES}

Aвbot RD, White LR, Ross GW, Masaki KH, Curb JD AND PETROVITCH H. 2004. Walking and dementia in physically capable elderly men. JAMA 292: 1447-1453.

Alaei H, Borjeian L, Azizi M, Orian S, PourshaNAZARI A AND HANNINEN O. 2006. Treadmill running reverses retention deficit induced by morphine. Eur J Pharmacol 536: 138-141.

Alaei H, Moloudi R and Sarkaki AR. 2008. Effects of treadmill running on mid-term memory and swim in the rat with Morris water maze test. J Bodywork Mov Ther 12: $72-75$.

Ang ET, Dawe GS, Wong PTH, Moochhala S AND NG YK. 2006. Alterations in spatial learning and memory after forced exercise. Brain Res 1113: 186-193.

Arida RM, Scorza CA, DA Silva AV, Scorza FA AND CAVAlheiro EA. 2004. Differential effects of spontaneous versus forced exercise in rats on the staining of parval-bumin-positive neurons in the hippocampal formation. Neurosci Lett 364: 135-138.

ARKIN S. 2007. Language-enriched exercise plus socialization slows cognitive decline in Alzheimer's disease. Am J Alzheimers Dis Others Demen 22: 62-77.

Barnes CA, Forster MJ, Fleshner M, Ahanotu EN, Laudenslager ML, Mazzeo RS, Maier SF and LAL H. 1991. Exercise does not modify spatial memory, brain autoimmunity, or antibody response in aged F-344 rats. Neurobiol Aging 12: 47-53.

Barros D, Amaral O, Izquierdo i, Geracitano L, Raseira MCB, Henriques AT and Ramirez MR. 2006. Behavioral and genoprotective effects of Vaccinium berries intake in mice. Pharmacol, Biochem and Behav 84: 229-234.

Berchtold NC, Chinn G, Chou M, Kesslak JP and COTMAN CW. 2005. Exercise primers a molecular memory for brain-derived neurotrophic factor protein induction in the rat hippocampus. Neuroscience 133: 853-861.

Blustein JF, MCLaughlin M and Holfman JR. 2006. Exercise effects stress-induced analgesia and spatial learning in rats. Physiol Behav 89: 582-586.

BROOKS GA AND WhITE TP. 1978. Determination of metabolic and heart rate responses of rats in treadmill exercise. J Appl Physiol 45: 1009-1015.

Cao L, Hudson CA and Moyninhan JA. 2007. Chronic foot shock induces behaviors and accompanying pro- and 
anti-inflammatory responses in mice. J Neuroimmunol 186: 63-74.

Cotman CW And Berchtold NC. 2002. Exercise: a behavioral intervention to enhance brain health and plasticity. Trends in Neurosci 25: 295-301.

Das A, Rai D, Dikshit M, Palit G and Nath C. 2005. Nature of stress: Differential effects on brain acetylcholinesterase activity and memory in rats. Life Sci 77: 2299-2311.

Dere E, Huston JP And Silva MAS. 2005. Integrated memory for objects, places, and temporal order: Evidence for episodic-like memory in mice. Neurobiol Learn Mem 84: 214-221.

DURING MJ AND CAO L. 2006. VEGF a mediator of the effect of experience on hippocampal neurogenesis. Curr Alzheimer Res 3: 29-33.

ENNAUCER A AND Delacour J. 1988. A new one-trail test for neurobiological studies of memory in rats. 1: Behavioral data. Behav Brain Res 31: 47-59.

Fabel K, Fabel K, TAm B, Kaufer D, Baiker A, SimMONS N, KuO CJ AND PALMER TD. 2003. VEGF is necessary for exercise-induced adult hippocampal neurogenesis. Eur J Neurosci 18: 2803-2812.

Frick KM, STILlNer ET AND Berger-SWEENEy J. 2000. Mice are not little rats: species differences in a one-day water maze task. Neuro Report 11: 3461-3465.

Huang AM, Jen CJ, Chen HF, Yu L, Kuo YM and CHEN HI. 2006. Compulsive exercise Acutely upregulates rat hippocampal brain-derived neurotrophic factor. J Neural transm 113: 803-811.

IsAacs KR, ANDERson BJ, Alcantara AA, Black JE AND GREENOUGH WT. 1992. Exercise and the brain: angiogenesis in the adult rat cerebellum after vigorous physical activity and motor skill learning. J Cereb Blood Flow Metab 12: 110-119.

Kramer AF et AL. 1999. Ageing, fitness and neurocognitive function. Nature 400: 418-419.

Manikandan S, Padma M, Srikumar K, ParthasaRathy NI, Muthuvel A AND Devi RS. 2006. Effects of chronic noise stress on spatial memory of rats in relation to neuronal dendritic alteration and free radicalimbalance in hippocampus and medial prefrontal cortex. Neurosci Lett 399: 17-22.

McEwen BS And Magarinos AM. 2001. Stress and hippocampal plasticity: implications for the pathophysiology of affective disorders. Hum Psychopharmacol 16: $117-127$
MCGAUGH JL. 2004. The amygdala modulates the consolidation of memories of emotionally arousing experiences. Annu Rev Neurosci 27: 1-28.

MCGAUGH JL. 2005. Emotional arousal and enhanced amygdala activity: new evidence for the old perseveration-consolidation hypothesis. Learn Mem 12: 77-79.

MCGAUGH JL. 2006. Make mild moments memorable: add a little arousal. Trends Cog Sci 10: 345-347.

Neeper SA, Goméz-Pinilla F, Choi J and Cotman C. 1995. Exercise and brain neurotrophins. Nature 373: 109.

Ogonovszky H, Berkes I, Kumagai S, Kaneko T, TAHARA S, Goto S AND RADAK Z. 2005. The effects of moderate-, strenuous- and overtraining on oxidative stress markers, DNA repair, and memory, in the rat brain. Neurochem Int 46: 635-640.

Radak Z, Told A, Szabo Z, Siamilis S, Nyakas C, Silye G, JAKus J AND Goto S. 2006. The effects of training and detraining on memory, neurotrophins and oxidative stress markers in rat brain. Neurochem Internat 49: $387-392$.

RADLEY JJ, ROChER AB, JANSSEN WG, HOF PR, MCEWEN BS AND MORRISON JH. 2005. Reversibility of apical dendritic retraction in the rat medial prefrontal cortex following repetead stress. Exp Neurol 196: 199203.

Rossato Ji, Bevilaqua LRM, Lima RH, Medina JH, IZQUIERdo I AND CAMMAROTA M. 2006a. On the participation of hippocampal p38 mitogen-activated protein kinase in extinction and reacquisition of inhibitory avoidance memory. Neuroscience 143: 15-23.

Rossato Ji, Bevilaqua LRM, Medina JH and CamMAROTA M. 2006b. Retrieval induces hippocampaldependent reconsolidation of spatial memory. Learn Mem 13: 431-440.

Rossato Ji, Bevilaqua LRM, Myskiw JC, Medina JH, IZQUIERDO I AND CAMMAROTA M. 2007. On the role of hippocampal protein synthesis in the consolidation and reconsolidation of object recognition memory. Learn Mem 14: 36-46.

Scopel D, Fochesatto C, Cimarosti H, Rabbo M, Belló-Klein A, Salbego C, Netto CA and SIQUEIRA IR. 2006. Exercise intensity influences cell injury in rat hippocampal slices exposed to oxygen and glucose deprivation. Brain Res Bull 71: 155-159.

Sutoo D And AkiYama K. 2003. Regulation of brain function by exercise. Neurobiol Dis 13: 1-14. 
Uysal N, Tugyan K, Kayatekin BM, Acikgoz O, BAgRiYANIK HA, GONENC S, OZ-DEMIR D, AKsu I, TOPCU A AND SEMIN I. 2005. The effects of regular aerobic exercise in adolescent period on hippocampal neuron density, apoptosis and spatial memory. Neurosci Lett 383: 241-245.

van Praag H, Christie BR, Sejnowski TJ and Gage FH. 1999. Running enhances neurogenesis, learning, and long-term potentiation in mice. Proc Natl Acad Sci USA 96: 13427-13431. van Praag H, Shubert T, Ahao C and Gage F. 2005. Exercise enhances learning and hippocampal neurogenesis in aged mice. J Neurosci 25: 8680-8685.

VAYNMAN SS, Ying Z, Yin D and GomeZ-Pinilla F. 2006. Exercise differentially regulates synaptic proteins associated to the function of BDNF. Brain Res 1070: 124-130.

Winter B ET AL. 2007. High impact running improves learning. Neurobiol Learn Mem 87: 597-609. 